\title{
Effect of hydroquinone and pyrocatechin on the corrosion and electrochemical behavior of steel in a model concrete pore liquid
}

\author{
I.A. Gedvillo, A.S. Zhmakina, N.N. Andreev* and S.S. Vesely \\ A.N. Frumkin Institute of Physical Chemistry and Electrochemistry, Russian Academy \\ of Sciences, Leninsky pr. 31, 119071 Moscow, Russian Federation \\ *E-mail: $\underline{\text { n.andreev@mail.ru }}$
}

\begin{abstract}
The effect of hydroquinone and pyrocatechin on the corrosion and electrochemical behavior of steel in a model concrete pore liquid has been studied. Corrosion tests have shown that hydroquinone and especially pyrocatechin can be superior in protective properties to sodium nitrite under conditions simulating the corrosion of steel reinforcement in concrete. It has been shown by electrochemical methods that the high efficiency of hydroquinone is observed under conditions of limited oxygen access into the system. It is due to oxygen scavenging and accordingly inhibition of the cathodic reaction. The protective ability of pyrocatechin, which is also capable of scavenging oxygen, is due to the inhibition of not only the cathodic process but also the local depassivation of steel. The mechanism of its inhibition is not quite clear and is possibly associated with inhibitor oxidation at anodic potentials. As a result, steel in fact becomes a non-polarizable electrode, and the potentials of its local depassivation, which are more positive than the potential of pyrocatechin oxidation, are not reached.
\end{abstract}

Keywords: steel, concrete, pore liquid, corrosion protection, inhibitors, hydroquinone, pyrocatechin.

Received: May 31, 2019. Published: July 22, 2019

doi: $\underline{10.17675 / 2305-6894-2019-8-3-7}$

\section{Introduction}

Metal corrosion inhibitors are widely used in various industries [1-3], including the construction industry, to protect steel reinforcement in concrete [4].

Reinforced concrete structures remain in service for many decades. However, the corrosive effect of industrial atmospheres, precipitation, and additives introduced into concrete during its mixing can lead to reinforcement corrosion.

Chlorides are the most dangerous in this respect. Small amounts of chlorides are bound by cement components and are not dangerous. However, if a certain critical threshold is exceeded, they can stimulate reinforcement corrosion, leading to the destruction of structures, which is sometimes of catastrophic nature [5-7].

The range of corrosion inhibitors for reinforcement in concrete structures in the presence of significant amounts of chlorides is quite limited. It is known that the following compounds may have such properties: 
- carboxylates and their salts $[8,9]$;

- amines and aminoalcohols [8, 10];

- certain compounds of other classes [8, 11-15].

However, these compounds are considerably inferior in protection efficiency to toxic nitrites and mixed inhibitors based on them that are traditionally used in concrete [16-20]. In view of this, searching for new compounds that provide reinforcement protection in the presence of significant amounts of chlorides is an important task.

According to our studies [21], phenol derivatives are a promising class of corrosion inhibitors for steel reinforcement in concrete. That is why in the present work we perform a comparative analysis of the efficiency of hydroquinone (HQ), pyrocatechin (PC) and sodium nitrite (hereinafter, nitrite) in a model pore fluid.

\section{Experimental}

All the compounds used in this study were of "chemically pure" grade.

Corrosion tests were performed using samples $(40 \times 20 \times 1 \mathrm{~mm})$ made of 08PS steel with a hole on one end. Samples were cleaned with sandpaper and degreased with alcohol.

A solution containing $1 \mathrm{~g} / 1 \mathrm{CaO}$ and $30 \mathrm{~g} / 1 \mathrm{NaCl}$ was used as the electrolyte simulating the concrete pore fluid.

Two series of experiments were performed. In the first series, the simulated solution was poured into plastic (PET) cells with a capacity of 0.51 containing weighted portions ( 0 to $30 \mathrm{~g} / 1$ ) of the compounds studied. After measuring the $\mathrm{pH}$ and, if necessary, adjusting it to $12.25 \pm 0.05$ with $\mathrm{NaOH}$ solution, steel samples were immersed in the electrolyte on nylon threads. The cells were tightly sealed. The time until the appearance of the first corrosion damage was recorded during daily visual inspections. The test duration was 30 days.

The second series of experiments was carried out similarly to the first one, but the cell lids were left open to provide free aeration of the solution. In this case, pre-weighted samples were used. At the end of exposure to the solution, the samples were removed, cleaned from corrosion products, and re-weighed. The corrosion rate was determined from mass loss data.

Polarization measurements were performed using a laboratory potentiostat in an electrochemical cell that allowed the electrolyte to be deaerated by nitrogen purging. The potential was measured relative to saturated silver chloride electrode, and a platinum mesh served as the auxiliary electrode. The working electrode had the form of a St3 steel cylinder with a surface of $5 \mathrm{~cm}^{2}$. One of its butt ends contained a threaded hole for attaching the metal holder rod and a sharp rim wedged into a Teflon holder washer insulating the rod from contact with the electrolyte.

The sample was placed into a cell with the model solution (with or without inhibitors) prepared in the same way as in the corrosion tests. After exposure for an hour and 
stabilization of the potential, cathodic and anodic polarization curves of steel were recorded. In this case, the potential of the steel electrode was shifted in the cathodic direction, stepwise at $0.1 \mathrm{~V}$ per minute, from the stationary value to $-0.8 \mathrm{~V}$ and back in the anodic direction to $+0.4 \mathrm{~V}$ or until the anodic current density reached values above $50 \mu \mathrm{A} / \mathrm{cm}^{2}$. The current values were recorded immediately before each potential step. In experiments with electrolyte deaeration, the cell and solution were purged with a stream of nitrogen. Gas purging was started immediately after the electrode was immersed in the electrolyte.

All the reported values are averages of 3-7 independent experiments.

\section{Results and Discussion}

Steel immersed in the model electrolyte underwent pitting corrosion, regardless of the aeration conditions. Even within the first day, depassivation sites covered with a "cap" of corrosion products appeared on the samples. All the additives studied inhibit the initiation of corrosion.

In a series of experiments carried out in tightly sealed plastic cells (Table 1), nitrite at a concentration of $C_{\mathrm{inh}}=2 \mathrm{~g} / \mathrm{l}$ provided complete protection of steel throughout the experiment. HQ and PC demonstrated higher efficiency. Their minimum protective concentrations were $1.0 \mathrm{~g} / 1$, but even $0.1 \mathrm{~g} / 1$ of HQ and PC increased the pitting incubation period 3- and 18-fold, respectively. It should be noted that it was the first time that we encountered individual compounds that were superior to nitrite under conditions simulating the corrosion of steel reinforcement in concrete. The plastic cells with HQ and PC solutions underwent considerable deformation during the experiments, which was apparently due to the ability of these compounds to consume oxygen [1]. This effect, along with the inhibition of the cathodic reaction or corrosion of steel itself, may explain the high efficiency of HQ and PC.

Table 1. Results of the corrosion test series in tightly sealed plastic cells.

\begin{tabular}{cccc}
\hline & \multicolumn{3}{c}{ Time until the appearance of corrosion, days } \\
\cline { 2 - 4 } $\boldsymbol{C}_{\text {inh }}, \mathbf{g} / \mathbf{l}$ & Sodium nitrite & HQ & PC \\
\hline 0.1 & 1 & 3 & 18 \\
\hline 1.0 & 1 & $>30$ & $>30$ \\
\hline 2.0 & $>30$ & $>30$ & $>30$ \\
\hline
\end{tabular}

To check this assumption, a second series of experiments was performed in open cells, as well as electrochemical studies in naturally aerated cells and in cells deaerated by bubbling of nitrogen (Table 2). 
Table 2. Results of the series of corrosion tests in open cells.

\begin{tabular}{|c|c|c|}
\hline$C_{\mathrm{inh}}, \mathrm{g} / \mathrm{l}$ & $K, \mathbf{g} /\left(\mathbf{m}^{2} \cdot \mathbf{d a y}\right)$ & Surface condition after the experiment \\
\hline- & 1.17 & The samples are stained with red corrosion products \\
\hline \multicolumn{3}{|r|}{ Nitrite } \\
\hline 1.0 & 2.02 & The samples are stained with red corrosion products \\
\hline 2.0 & 0.90 & The samples are stained with red corrosion products \\
\hline 4.0 & 0.01 & Local corrosion sites in the area of sample mounting \\
\hline 10.0 & 0.1 & No corrosion \\
\hline 30.0 & 0.00 & No corrosion \\
\hline \multicolumn{3}{|r|}{ HQ } \\
\hline 1.0 & 0.41 & The samples are covered with a black deposit with multiple pits \\
\hline 2.0 & 0.15 & The samples are covered with a gray film with blue tint and with single pits \\
\hline 4.0 & 0.43 & The samples are covered with a gray film with blue tint. Local corrosion sites \\
\hline 10.0 & 1.10 & The samples are covered with a gray film with blue tint. Local corrosion sites \\
\hline 30.0 & 2.16 & $\begin{array}{l}\text { The samples are covered with a gray film with dark spots. Local corrosion } \\
\text { sites }\end{array}$ \\
\hline \multicolumn{3}{|r|}{ PC } \\
\hline 1.0 & 0.02 & Local corrosion sites \\
\hline 2.0 & 0.09 & $\begin{array}{l}\text { The samples are covered with a film with annealing colors, no local corrosion } \\
\text { sites }\end{array}$ \\
\hline 4.0 & 0.06 & The samples are covered with a film with blueish tint, no local corrosion sites \\
\hline 10.0 & 0.06 & The samples are covered with a film with blueish tint, no local corrosion sites \\
\hline 30.0 & 0.00 & No visible film. No corrosion \\
\hline
\end{tabular}

In the absence of inhibitive additives, the corrosion rate of steel in open cells was $1.17 \mathrm{~g} /\left(\mathrm{m}^{2}\right.$-day $)$. Samples after the experiments were covered with corrosion products that occupied $20-30 \%$ of the area.

Addition of $1 \mathrm{~g} / 1$ nitrite stimulated the corrosion. Its rate increased almost twofold, i.e., to $2.02 \mathrm{~g} /\left(\mathrm{m}^{2} \cdot\right.$ day $)$. This confirms once again the well-known fact that nitrite is a dangerous corrosion inhibitor. The appearance of samples after the test little differed from the appearance of reference samples.

An increase in the nitrite concentration decreased the corrosion rate. Already at $C_{\text {inh }}=4 \mathrm{~g} / 1$, its value decreased to $0.01 \mathrm{~g} /\left(\mathrm{m}^{2} \cdot\right.$ day $)$, while $10 \mathrm{~g} / 1$ suppressed steel dissolution completely. The minimum protective concentration of nitrite in naturally 
aerated electrolyte in open cells exceeded this parameter determined in the first series of tests.

HQ inhibited corrosion at low concentrations more than 2-fold at $C_{\text {inh }}=1 \mathrm{~g} / 1$ and almost 8 -fold at $2 \mathrm{~g} / \mathrm{l}$. In the latter case, the samples were covered with a gray film with blue tint and single pits. However, HQ did not provide complete metal protection. An increase in $C_{\text {inh }}$ in the electrolyte up to $30 \mathrm{~g} / 1$ not only failed to suppress corrosion but even activated it markedly. The mass loss of steel increased above its level for the reference samples. This confirms the assumption that the high anticorrosive properties of HQ in the series of experiments in sealed cells are mainly due to oxygen consumption and inhibition of the cathodic process.

PC possessed the highest protective properties among the inhibitors studied under our experimental conditions. Even at $C_{\text {inh }}=2 \mathrm{~g} / 1, \mathrm{PC}$ prevented the pitting on steel completely. In this case, metal samples were covered with a film with annealing colors, but there were no local corrosion sites on the metal. The mass loss of the samples, which were apparently related to the formation of a protective film, decreased by a factor of 13 relative to the blank test. An increase in the PC concentration to 4 or $10 \mathrm{~g} / 1$ did not change the appearance of the samples. The corrosion rate decreased to $0.06 \mathrm{~g} /\left(\mathrm{m}^{2} \cdot\right.$ day $)$. A protective film with a bluish tint visible to naked eye was present on the samples. $30 \mathrm{~g} / 1 \mathrm{of} P C$ completely prevented the corrosion and formation of a visible film. In this case, the appearance of samples did not change throughout the test.

The protective properties of PC in naturally aerated cells, which are high compared to HQ, could be due to more efficient inhibition of the cathodic process and/or inhibition of the pitting process.

Electrochemical experiments were carried out to clarify the mechanism of steel protection with HQ and PC.

After immersing steel into a naturally aerated model electrolyte containing no inhibitors, its potential shifted in the cathodic direction for 40-50 minutes and then stabilized at -0.30 to $-0.32 \mathrm{~V}\left(E_{\text {start }}\right)$.

During cathodic polarization of the electrode, hysteresis was observed on the curves at the forward and reverse runs (Figure 1). Two regions could be distinguished on the curves of the direct run. The first one, from $E_{\text {start }}$ to $E \sim-0.6 \mathrm{~V}$, was characterized by a relatively weak growth of the cathodic current related to diffusion-limited reduction of oxygen dissolved in the electrolyte. Further cathodic polarization of steel (below $-0.6 \mathrm{~V}$ ) led to a sharp increase in the cathodic current. The air-formed passive film was reduced in this region, and perhaps hydrogen was evolved.

The reverse run of polarization curves was characterized by smaller cathodic currents than the direct run. This is due to the fact that the surface oxide on steel was already absent and cathodic current was no longer spent for its reduction. The absence of oxide activated the processes of steel dissolution, and at $E \sim-0.4$ the cathodic current changed direction to become anodic. In the $E$ range from -0.4 to $-0.2 \mathrm{~V}$, the anodic currents increased weakly. The presence of this region resulted from the formation of an oxide passive film on the 
steel surface. Further anodic polarization of the electrode led to depassivation of the electrode (at $-0.2 \mathrm{~V}$ ) and formation of local dissolution sites on it in the form of pits visible with naked eye when samples were inspected after the experiment.

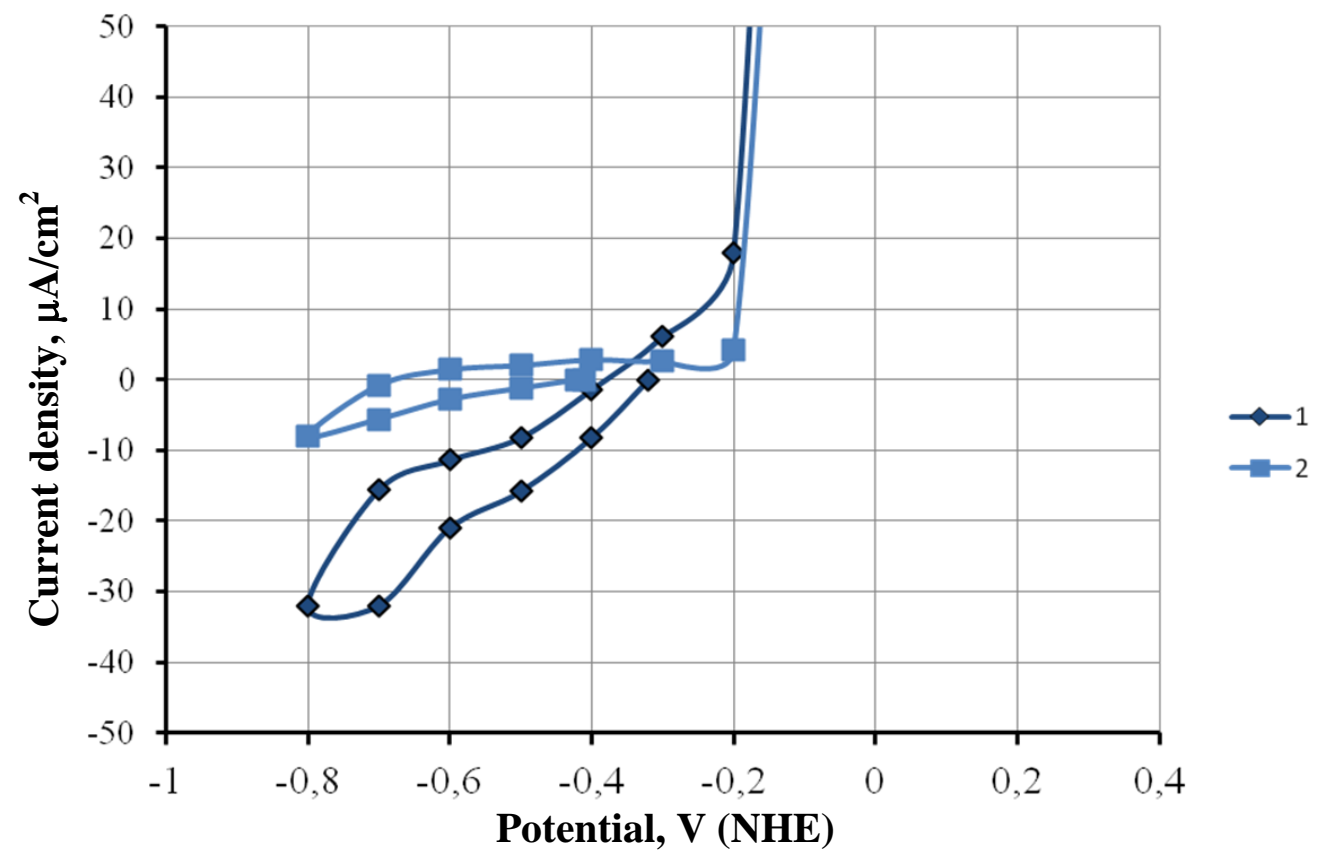

Figure 1. Polarization curves of St3 steel in the model solution with natural aeration (1) and deaeration (2).

Purging the cell with nitrogen shifted $E_{\text {start }}$ in the negative direction to $-0.40 \ldots$ $-0.42 \mathrm{~V}$, which indicated the inhibition of the cathodic process. Indeed, it decreased manifold the cathodic currents during the forward and reverse polarization runs due to the removal of dissolved oxygen from the electrolyte. During reverse polarization, the equality of the anodic and cathodic currents was achieved already at $E=-0.7 \mathrm{~V}$. An extended passive region was observed at more positive potentials. Only at $E=-0.2 \mathrm{~V}$, the anodic current sharply increased due to the local depassivation of steel. The initiation of the pitting process in naturally aerated and deaerated electrolytes occurred at nearly the same potentials.

Addition of sodium nitrite to naturally aerated electrolyte resulted in ennoblement of $E_{\text {start }}$ that increased symbatically with the additive amount. While at a nitrite concentration of $0.5 \mathrm{~g} / 1, E_{\text {start }}$ shifted in the positive direction by less than $0.1 \mathrm{~V}$, the potential shift exceeded $0.3 \mathrm{~V}$ at $4 \mathrm{~g} / \mathrm{l}$.

Analysis of the polarization curves indicates that this shift of $E_{\text {start }}$ was due to simultaneous activation of the cathodic process and inhibition of the anodic one (Figure 2). Like in the case described above, a hysteresis was observed on the polarization curves. Moreover, the cathodic currents both during the forward and reverse polarization runs in the electrolyte inhibited by nitrite significantly exceeded the corresponding values 
measured in the blank experiment. In addition, nitrite noticeably slowed down the local anionic depassivation of the electrode. On the anodic branches of polarization curves, the pitting potential shift was 0.1 and $0.3 \mathrm{~V}$ in solutions containing 0.5 and $4 \mathrm{~g} / 1$ of nitrite, respectively.

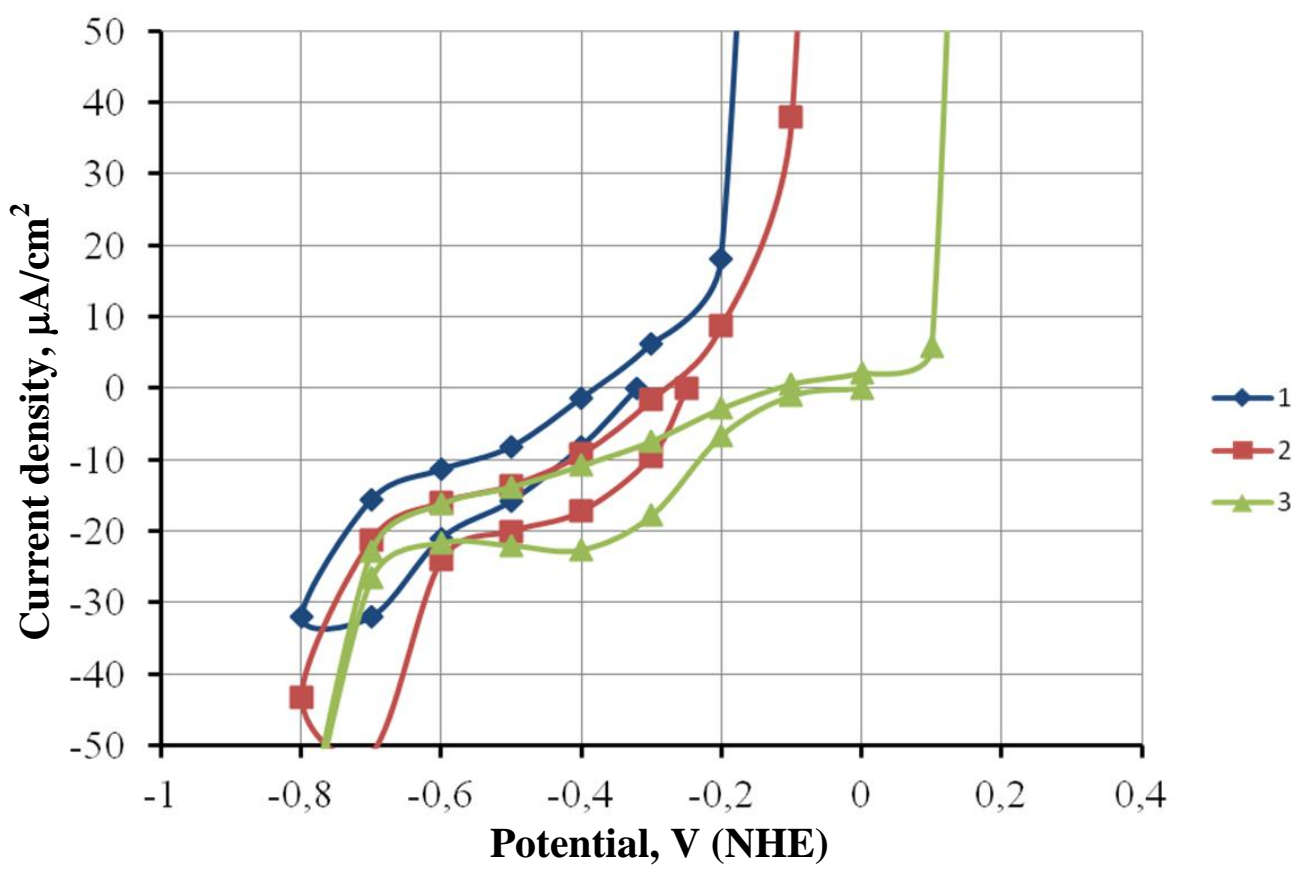

Figure 2. Polarization curves of St3 steel in the model solution with natural aeration (1) and with addition of $0.5 \mathrm{~g} / \mathrm{l}(2)$ or $4 \mathrm{~g} / \mathrm{l}$ (3) nitrite.

In deaerated solutions, low concentrations of nitrite $(0.5 \mathrm{~g} / \mathrm{l})$ nearly did not affect the electrochemical behavior of steel (Figure 3). A higher content $(4 \mathrm{~g} / \mathrm{l})$ of nitrite markedly activated the cathodic process and inhibited the anodic process of metal dissolution. The ennoblement of the pitting potential caused by this additive equals the value recorded in naturally aerated electrolytes.

Addition of $0.5 \mathrm{~g} / 1 \mathrm{HQ}$ to the aerated electrolyte slightly increased the $E_{\text {start }}$ of steel (Figure 4). Conversely, addition of $4 \mathrm{~g} / \mathrm{l} \mathrm{HQ}$ shifted $E_{\text {start }}$ in the negative direction, while the diffusion currents of oxygen reduction sharply decreased. This decrease was apparently due to the consumption of oxygen by HQ, a strong reducing agent.

A pronounced passivity region covering $0.4-0.5 \mathrm{~V}$ can be seen on the reverse curves. It changes to a sharp increase in the anodic current at $E=-0.2$ to $-0.1 \mathrm{~V}$ accompanied by the appearance of localized dissolution sites on the electrode surface. Unlike nitrite, HQ did not cause a noticeable inhibition of the anodic process. The potentials corresponding to a sharp increase in the anodic current in the presence and absence of HQ were nearly the same. 


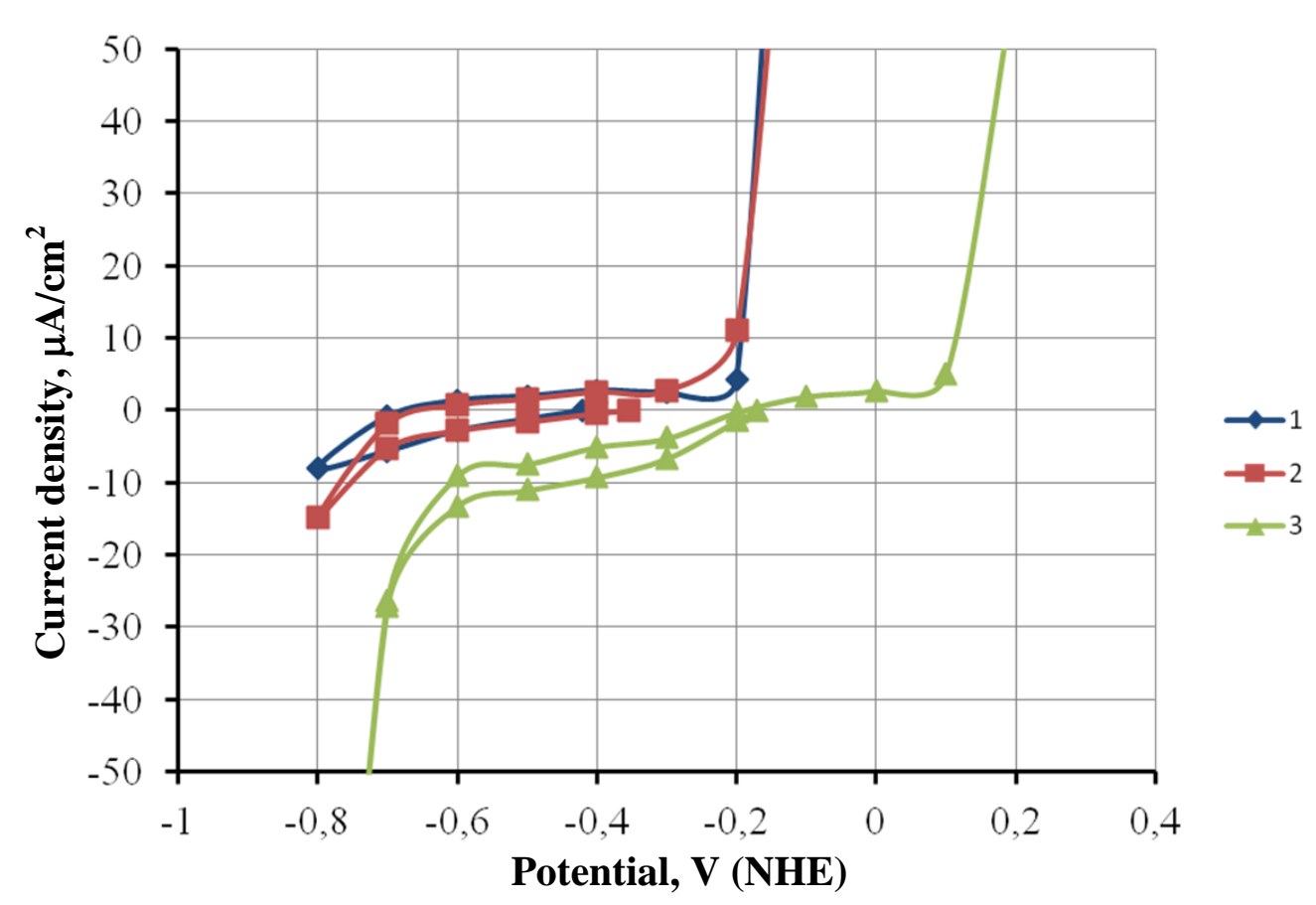

Figure 3. Polarization curves of St3 steel in the deaerated model solution (1) with addition of $0.5 \mathrm{~g} / \mathrm{l}(2)$ or $4 \mathrm{~g} / \mathrm{l}(3)$ nitrite.

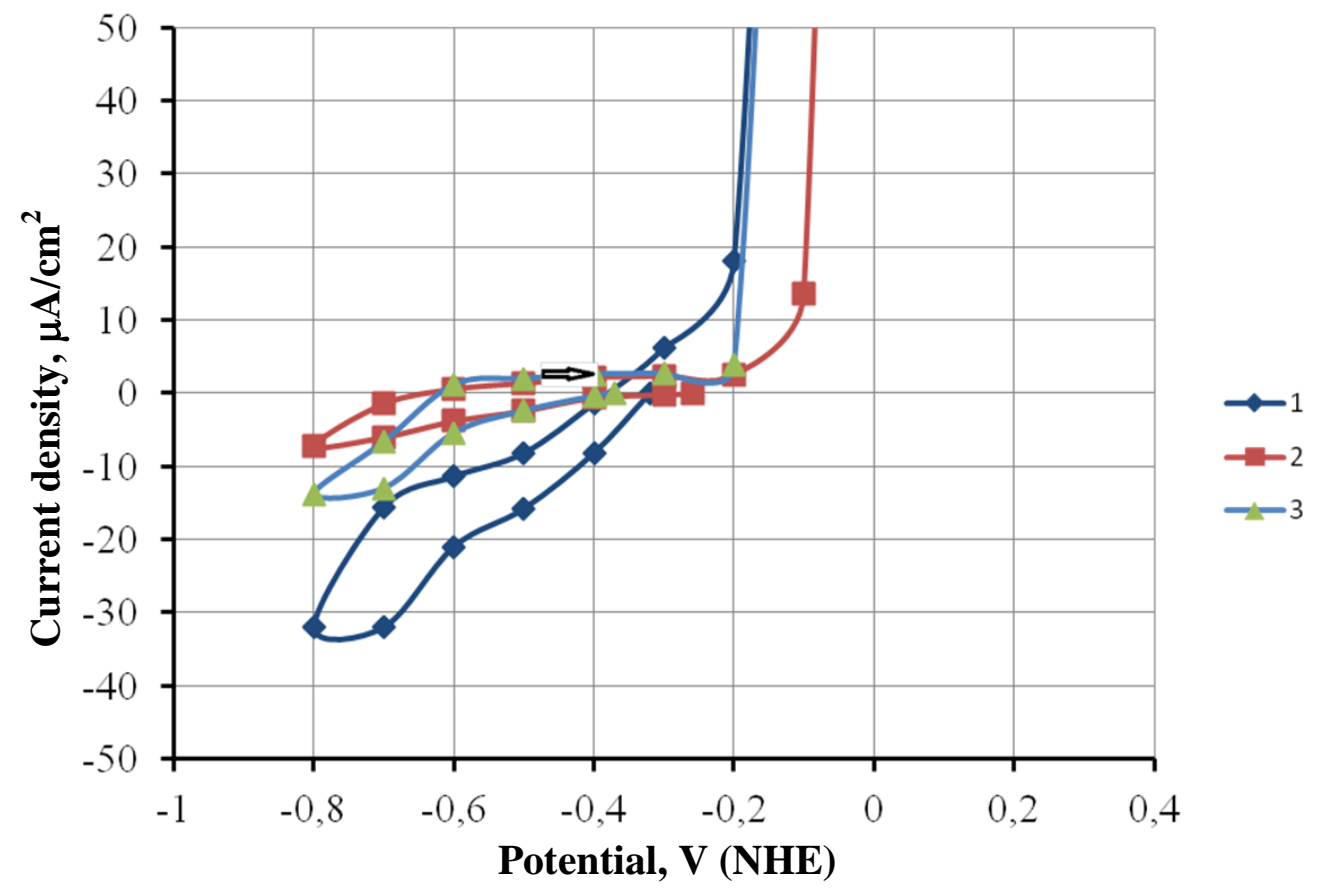

Figure 4. Polarization curves of St3 steel in the model solution with natural aeration (1) or with addition of $0.5 \mathrm{~g} / \mathrm{l}(2)$ or $4 \mathrm{~g} / \mathrm{l}(3) \mathrm{HQ}$.

In deaerated electrolyte, HQ shifted $E_{\text {start }}$ in the positive direction by $0.1-0.15 \mathrm{~V}$, regardless of the additive concentration (Figure 5). The direct and reverse cathodic curves in the presence of various HQ concentrations almost coincided in the potential range 
$E \geq-0.6 \mathrm{~V}$. The background polarization curves were characterized by lower currents. The potentials of the sharp increase in anodic currents determined in experiments without purging electrolyte with nitrogen were identical.

Thus, electrochemical measurements confirm the assumption that the high efficiency of HQ in the first series of corrosion tests was due to the consumption of oxygen and associated inhibition of the cathodic process.

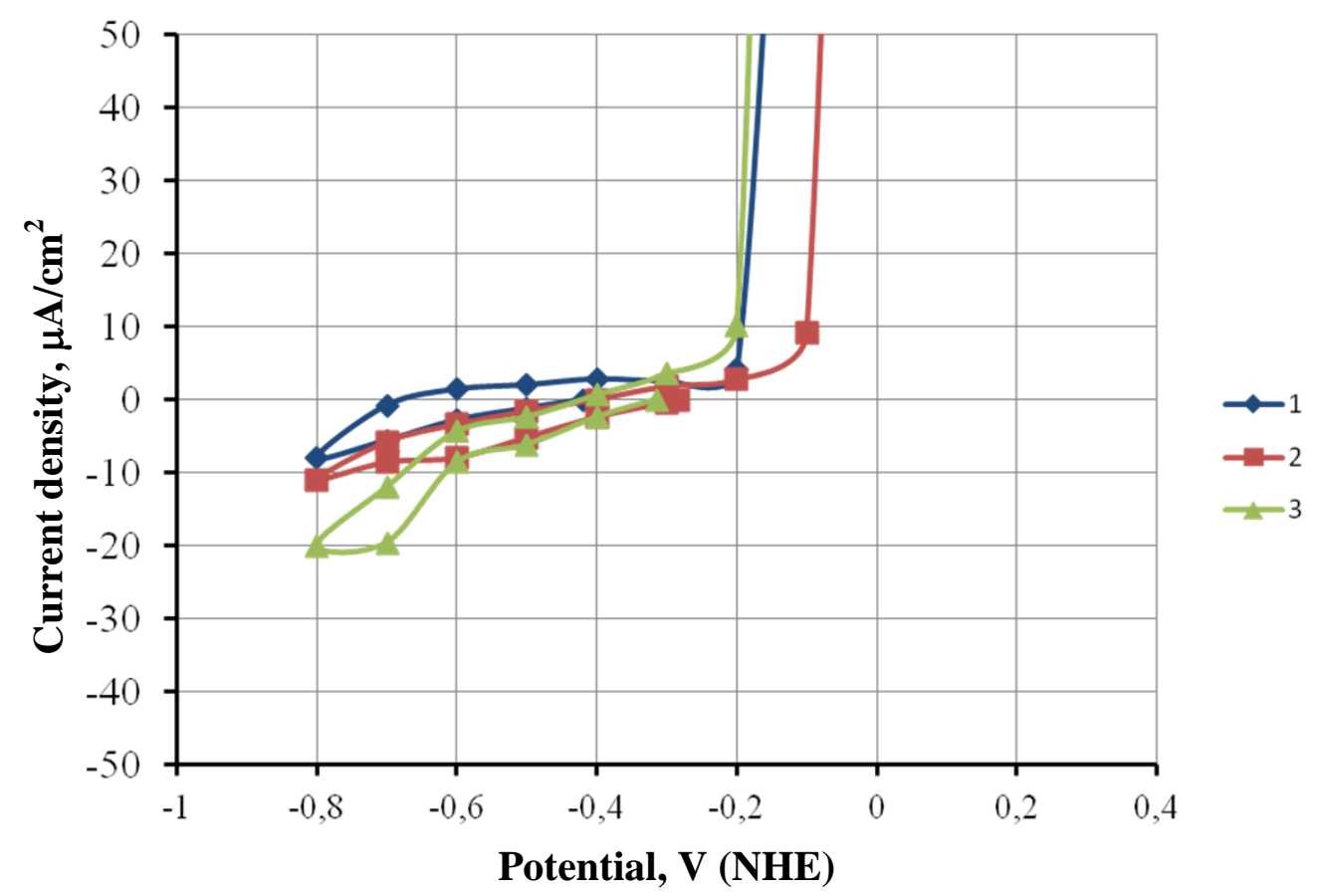

Figure 5. Polarization curves of St3 steel in the deaerated model solution (1) with addition of $0.5 \mathrm{~g} / \mathrm{l}$ (2) or $4 \mathrm{~g} / \mathrm{l}$ (3) HQ.

In naturally aerated solutions, PC in the concentrations studied did not affect the values of $E_{\text {start }}$ that were equal within the measurement error and lay in the $E$ range from -0.27 to $-0.32 \mathrm{~V}$ (Figure 6). Like HQ, PS consumed oxygen and markedly slowed down the cathodic process during direct cathodic polarization. In reverse polarization curves, cathodic currents turned to anodic ones already at $E=-0.6 \mathrm{~V}$ at a PC concentration of $0.5 \mathrm{~g} / 1$ and $-0.7 \mathrm{~V}$ at $4 \mathrm{~g} / 1$. At lower $C_{\text {inh }}$ values, the anodic curves contained a long passivity region (about $0.5 \mathrm{~V}$ ), which changed to a sharp increase in the anodic current at $E=-0.2 \mathrm{~V}$. At $C_{\mathrm{PC}}=4 \mathrm{~g} / 1$, a region of active dissolution of the metal was observed on the anodic polarization curves at $E=-0.7$ to $-0.5 \mathrm{~V}$. The total passivation currents did not exceed $10 \mu \mathrm{A} / \mathrm{cm}^{2}$ but were well reproducible between experiments. The active dissolution of the metal in the alkaline electrolyte is most likely due to reduction of surface oxides responsible for the passivity by PC.

Active dissolution changed to a passive region ca. $0.4 \mathrm{~V}$ long. The anodic currents increased sharply at $E=-0.2$ to $-0.1 \mathrm{~V}$. It is important that visual inspection of samples 
extracted from the electrolyte at these potentials did not allow us to conclude definitely that the increase in current was due to pitting.

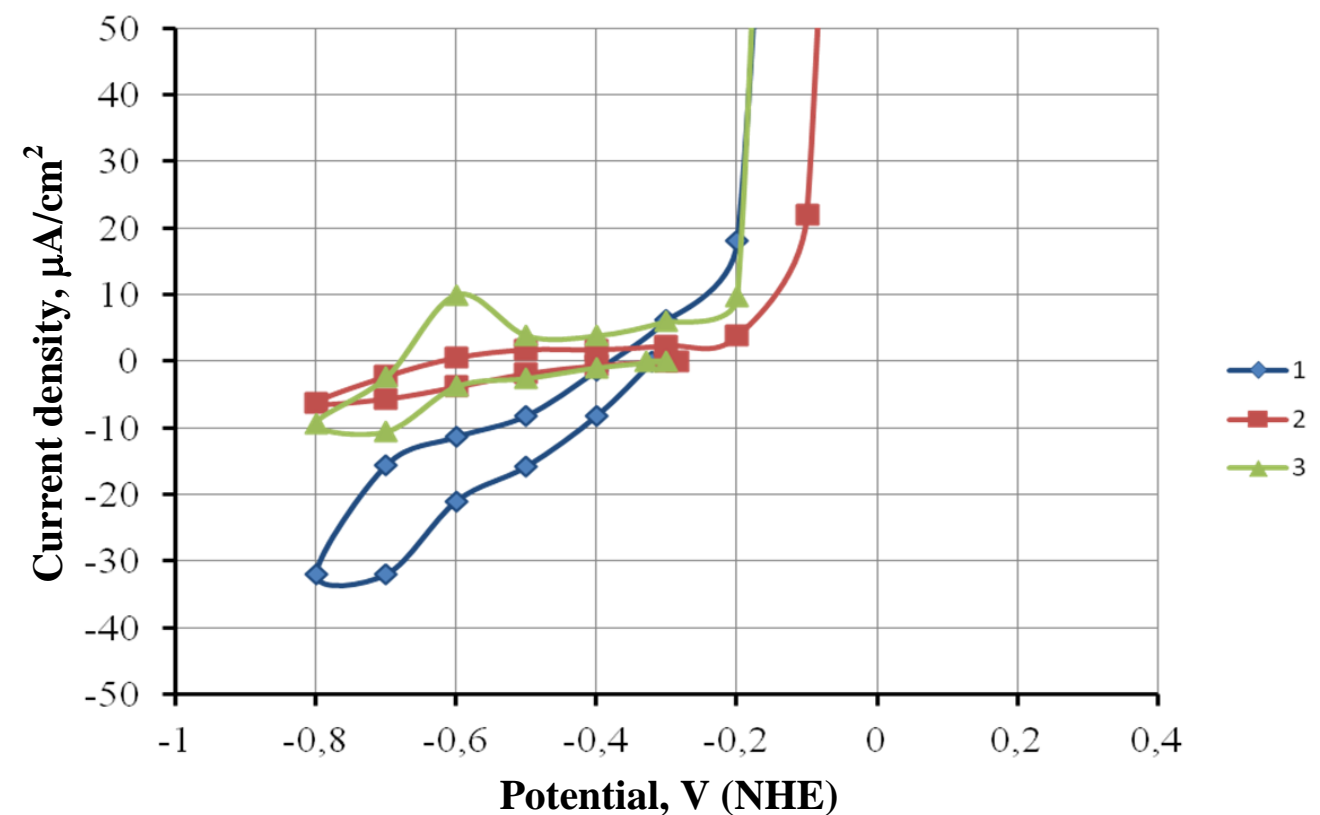

Figure 6. Polarization curves of $\mathrm{St} 3$ steel in the model solution with natural aeration without additives (1) or with addition of $0.5 \mathrm{~g} / \mathrm{l}$ (2) or $4 \mathrm{~g} / \mathrm{l}$ (3) PC.

Purging the electrolyte with nitrogen did not change the characteristic potentials and the general shape of the polarization curves. The only significant difference was that there was no region of steel active dissolution (Figure 7).

Thus, polarization measurements do not allow us to fully understand the reasons for the higher protective properties of PC compared to HQ noted in corrosion tests. Indeed, both substances almost equally hinder the cathodic process of oxygen reduction and equally weakly, in comparison with nitrite, affect the potentials of sharp current increase on the anodic curves.

One of the possible explanations for the advantages of PC compared to HQ may be that the sharp increase in current on the anodic curves for this substance is associated with PC oxidation rather than with pitting. As a result, steel in fact becomes a non-polarizable electrode, and the potentials of its local depassivation, which are more positive than the potential of pyrocatechin oxidation, are not reached.

This assumption is indirectly confirmed by the anodic polarization curves obtained in chloride-free model PC solutions (Figure 8). On these curves, after a small passive region, there is a sharp rise in current that is not accompanied by the formation of pits on the metal and is due to the anodic oxidation of the inhibitor itself.

An argument against this assumption is that the oxidation potentials of PC $(0.0-0.1 \mathrm{~V})$ are higher than the pitting potentials in the chloride-containing model solution. 


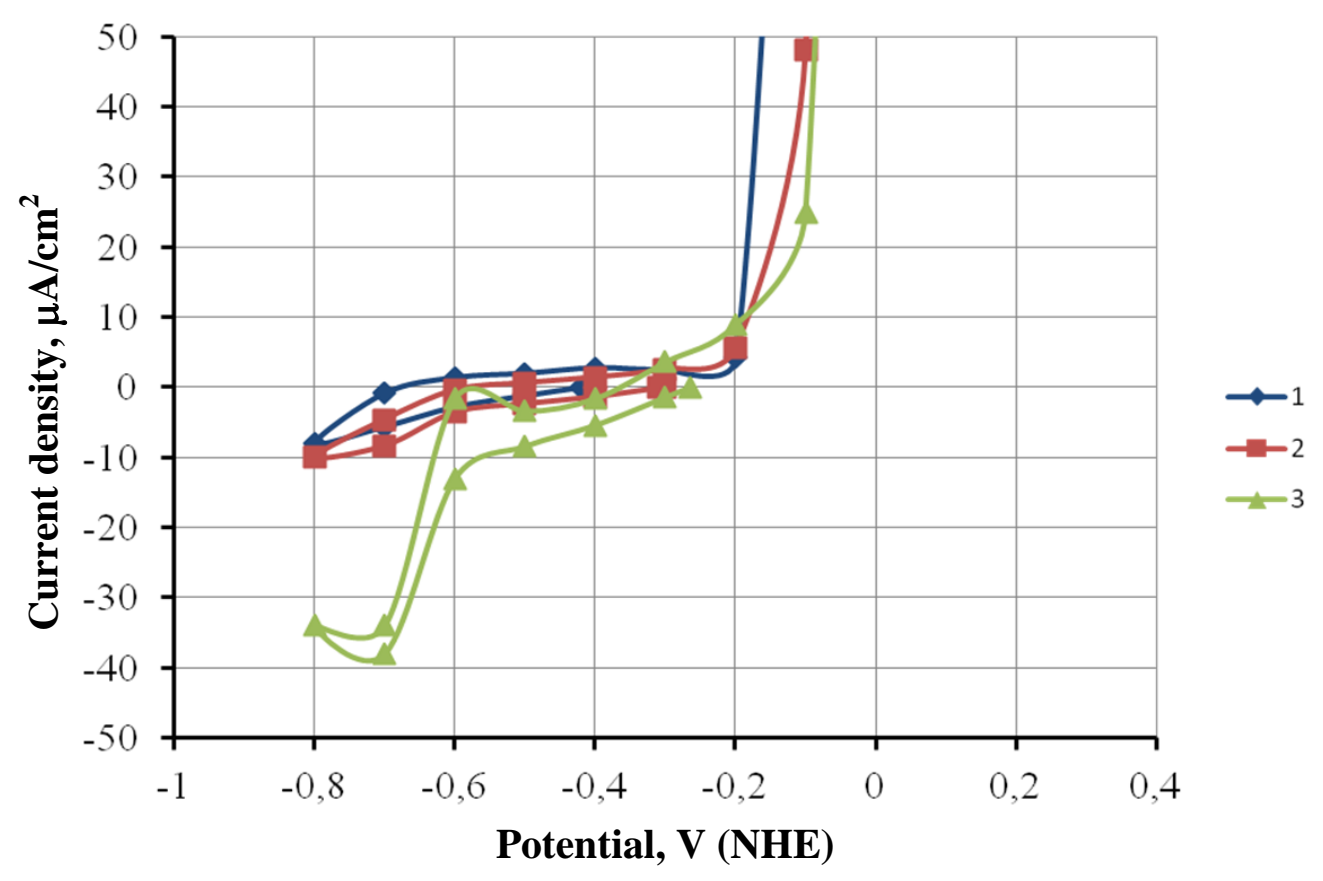

Figure 7. Polarization curves of St 3 steel in the deaerated model solution (1) with addition of $0.5 \mathrm{~g} / \mathrm{l}(2)$ or $4 \mathrm{~g} / \mathrm{l}(3)$ PC.

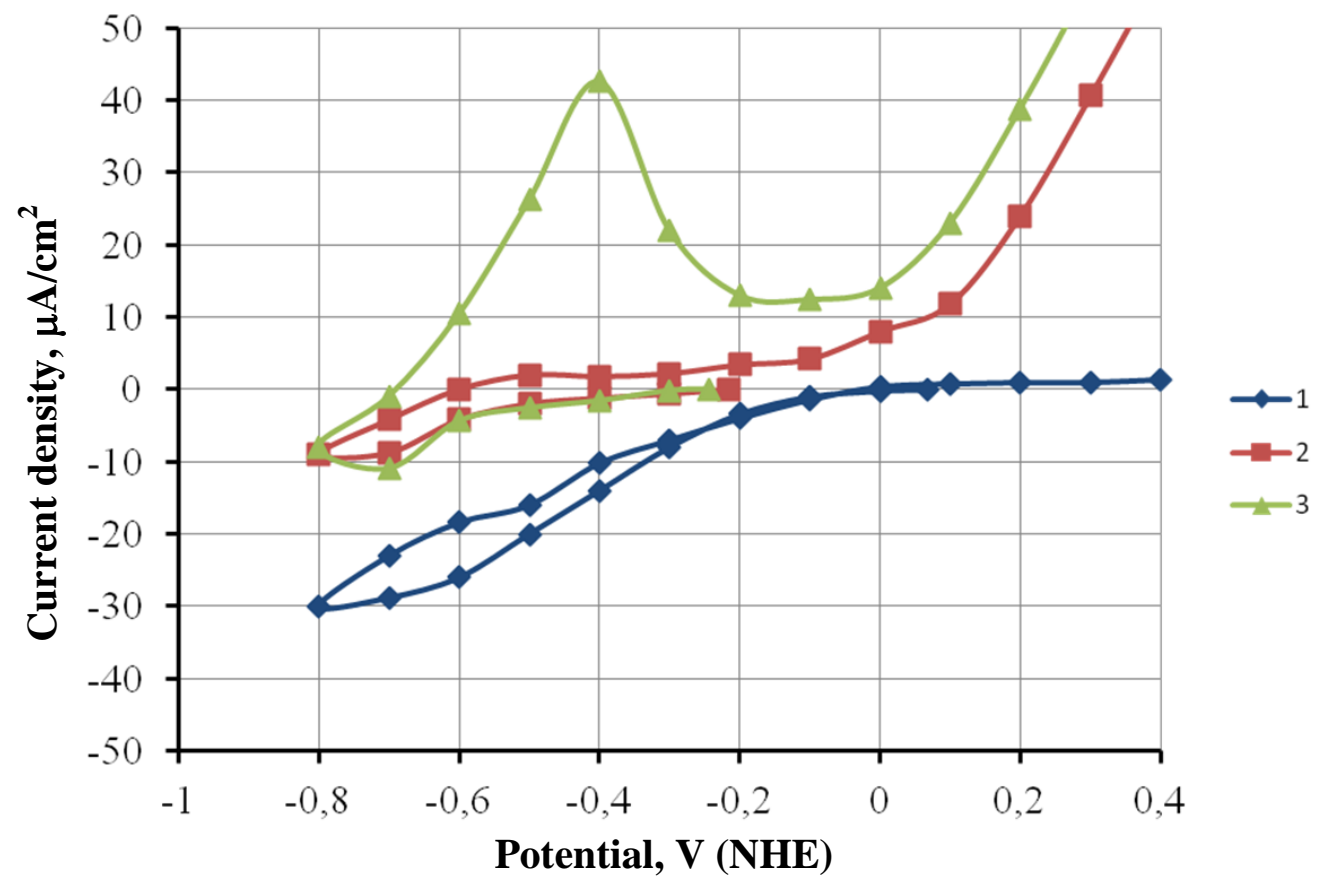

Figure 8. Polarization curves of St3 steel in the model solution with natural aeration without chlorides (1) and with addition of $0.5 \mathrm{~g} / \mathrm{l}$ (2) or $4 \mathrm{~g} / \mathrm{l}$ (3) PC.

In any case, since we are talking about a promising new class of corrosion inhibitors for steel reinforcement in concrete, this assumption about the mechanism of the protective action of PC requires deeper studies. It will be done in one of our subsequent studies where 
special attention will be paid to monitoring the $\mathrm{pH}$ changes during corrosion and electrochemical measurements.

\section{Conclusions}

1. It has been shown that hydroquinone and especially pyrocatechin can be superior in protective properties to nitrite under conditions simulating the corrosion of steel reinforcement in concrete.

2. The high efficiency of HQ in a series of corrosion tests in tightly sealed cells is due to the ability of this compound to consume oxygen and inhibit the cathodic reaction.

3. The protective ability of pyrocatechin, which is also capable of consuming oxygen, is due to the inhibition of not only the cathodic process but also the local depassivation of steel. The inhibition mechanism of the latter is not quite clear and is possibly associated with the oxidation of the inhibitor.

\section{References}

1. I.L. Rozenfel'd, Ingibitory korrozii (Corrosion inhibitors), 1977, Moscow, Khimiya (in Russian).

2. L.I. Antropov, E.M. Makushin and V.F. Panasenko, Ingibitory korrozii metallov (Metal Corrosion Inhibitors), Kiev, Tekhnika, 1981 (in Russian).

3. Yu.I. Kuznetsov, Organic inhibitors of corrosion of metals, N.Y.: Plenum Press, 1996, 283.

4. S.N. Alekseev, V.B. Ratinov, N.K. Rozental' and N.M. Kashurnikov, Inhibitors of steel corrosion in reinforce concrete structures, Moscow, Stroiizdat, 1985 (in Russian).

5. S.N. Alekseev, Corrosion and protection of reinforcement in concrete, Moscow, Stroiizdat, 1968 (in Russian).

6. L. Bertolini, B. Elsener, P. Pedeferri, E. Redaelli and R. Polder, Corrosion of steel in concrete, Weinheim, Germany, Wiley-Vch, 2013.

7. U. Angst, B. Elsener, C.K. Larsen and Ø. Vennesland, Critical chloride content in reinforced concrete - a review, Cem. Concr. Res., 2009, 39, no. 12, 1122-1138.

8. F. Bolzoni, A. Brenna, G. Fumagalli, S. Goidanich, L. Lazzari, M. Ormellese and MP Pedeferri, Experiences on corrosion inhibitors for reinforced concrete, Int. J. Corros. Scale Inhib., 2014, 3, no. 4, 254-278. doi: 10.17675/2305-6894-2014-3-4-254$\underline{278}$

9. N.N. Andreev, E.V. Starovoitova and N.A. Lebedeva, Inhibition of steel corrosion by salts of benzoic acids in calcium hydroxide solutions, Korroz.: Mater., Zashch. (Corrosion: Materials, Protection), 2007, no. 5, 29-31 (in Russian).

10. N.N. Andreev, E.V. Pichugina and N.A. Lebedeva, About the inhibition of steel corrosion in calcium hydroxide solutions by amines and aminoalcohols, Korroz.: Mater., Zashch. (Corrosion: Materials, Protection), 2005, no. 7, 21-24 (in Russian). 
11. M. Ormellese, M. Berra, F. Bolzoni and T. Pastor, Corrosion inhibitors for chlorides induced corrosion in reinforced concrete structures, Cem. Concr. Res., 2006, no. 3 , $536-547$.

12. T.A. Söylev and M.G. Richardson, Corrosion inhibitors for steel in concrete: State-ofthe-art report, Constr. Build. Mater., 2008, 22, no. 4, 609-622.

13. C.L. Page, V.T. Ngala and M.M. Page, Corrosion inhibitors in concrete repair systems, Mag. Concr. Res., 2000, 52, no. 1, 25-37.

14. C. Monticelli, A. Frignani and G. Trabanelli, A study on corrosion inhibitors for concrete application, Cem. Concr. Res., 2000, 30, no. 4, 635-642.

15. J.M. Gaidis, Chemistry of corrosion inhibitors, Cem. Concr. Compos., 2004, 26, no. 3 , $181-189$.

16. N.S. Berke and M.C. Hicks, Predicting long-term durability of steel reinforced concrete with calcium nitrite corrosion inhibitor, Cem. Concr. Compos., 2004, 26, no. 3, 191-198.

17. E.V. Starovoitova, N.N. Andreev, I.A. Gedvillo and A.S. Zhmakina, Nitrote-benzoate inhibitors for corrosion protection of steel reinforcement in concrete, Korroz.: Mater., Zashch. (Corrosion: Materials, Protection), 2009, no. 6, 30-33 (in Russian).

18. N.N. Andreev, I.A. Gedvillo, A.S. Zhmakina, D.S. Bulgakov and E.V. Starovoitova, Physicochemical principles in development of migrating corrosion inhibitors for steel reinforcement in concrete, Vestnik TGU, 2013, 18, no. 5, 2269-2274 (in Russian).

19. N.N. Andreev, I.A. Gedvillo, A.S. Zhmakina, T.L. Zimina, V.F. Stepanova and L.P. Kharitonova, Comparison of protective properties of migrating corrosion inhibitors, Prakt. Protivokorroz. Zashch., 2014, no. 1, 14-16 (in Russian).

20. K.Y. Ann, H.S. Jung, H.S. Kim, S.S. Kim and H.Y. Moon, Effect of calcium nitritebased corrosion inhibitor in preventing corrosion of embedded steel in concrete, Cem. Concr. Res., 2006, 36, no. 3, 530-535.

21. I.A. Gedvillo, A.S. Zhmakina and N.N. Andreev, Steel corrosion inhibition in model concrete porous liquid by phenol derivatives, Prakt. Protivokorroz. Zashch., 2019 (in Russian) (in press). 